\title{
SEASONAL DYNAMICS OF ARBUSCULAR MYCORRHIZAL FUNGI IN PLANTS OF THEOBROMA GRANDIFLORUM SCHUM AND PAULLINIA CUPANA MART. OF AN AGROFORESTRY SYSTEM IN CENTRAL AMAZONIA, AMAZONAS STATE, BRAZIL
}

\author{
Arlem Nascimento de Oliveira ${ }^{1}$; Luiz Antonio de Oliveira ${ }^{2 *}$ \\ ${ }^{1}$ Universidade Federal do Amazonas, Manaus, AM, Brasil. ${ }^{2}$ Laboratório de Microbiologia do Solo, Coordenação de Pesquisas \\ em Ciências Agronômicas, Instituto Nacional de Pesquisas da Amazônia, Manaus, AM, Brasil
}

Submitted: November 23, 2004; Returned to authors for corrections: April 27, 2005; Approved: September 15, 2005

\begin{abstract}
The seasonal dynamics of Arbuscular Mycorrhizal Fungi (AMF) was investigated in the rhizosphere of two fruit species in a terra firme (upland) ecosystem in Central Amazonia. Two host species (Theobroma grandiflorum and Paullinia cupana) and nine sampling months (August, September and December/1998, February, April, May and December/1999, February and May/2000) were studied in a completely randomized design, with five replications, set in a 2 x 9 factorial experiment. Soil $(0-20 \mathrm{~cm}$ depth) and root samples were collected between August 1998 and May 2000. The mean percent colonization of AMF for both species reached maximal values in February and May 2000 (rainy season). In April and May 1999, February and May 2000 (rainy season) the highest AMF spore numbers were registered. The pluvial precipitation was significantly positively correlated with AMF number spores for both fruit species, and significant positive correlation only with AMF colonization of $P$. cupana. Soil moisture content was positively correlated with colonization and spore numbers of AMF for both species evaluated. AMF colonization and AMF spore numbers of $T$. grandiflorum were positively correlated with soil $\mathrm{Mg}$ and $\mathrm{K}$ concentrations. AMF spore numbers of $T$. grandiflorum were also negatively correlated with effective cation exchange capacity (ECEC). AMF colonization and AMF spore numbers in the rhizosphere of $P$. cupana were positively correlated with $\mathrm{pH}$ and $\mathrm{Mn}$ concentrations. AMF colonization was also positively correlated with AMF spore numbers for both species evaluated. In conclusion, this study showed that AMF colonization and sporulation are seasonal and dependent on host plant species, pluvial precipitation, soil moisture content and soil chemistry in Central Amazonia conditions.
\end{abstract}

Key words: arbuscular mycorrhizal fungi, Theobroma grandiflorum, Paullinia cupana, agroforestry system, Central Amazonia

\section{INTRODUCTION}

The ecology and dynamic of soil microorganisms vary both temporally and spatially (31). Environmental factors that affect and alter soil microbial assemblage structure and function are complex. It is well known that environmental variables, such as soil $\mathrm{pH}$, nutrient availability and soil moisture content, can influence the distribution and activity of soil microorganisms
$(2,16)$. In terra firme ecosystems in Amazonia, high soil acidity and low fertility are limit microbial activities. However, changes in $\mathrm{pH}$ and inorganic nutrient availability are triggered by pattern as in soil moisture (42).

Arbuscular mycorrhizal fungi (AMF) are a major component of rhizosphere microflora in natural ecosystems, and play significant roles in the mineralization and cycling of plant nutrients $(3,33)$. AMF increase the efficiency of nutrient and

*Corresponding Author. Mailing address: Coordenação de Pesquisas em Ciências Agronômicas (CPCA/INPA). Av. André Araújo, 2936, Bairro Petrópolis, Caixa Postal 478. 69011-970, Manaus, AM, Brasil. E-mail: luizoli@inpa.gov.br 
water absorption and host plant response to stressful environments (55). AMF also contribute to the maintenance of good soil structure $(55,60)$.

The development and seasonal fluctuations in AMF fungus has been investigate in several plant species and in several countries, including the Great Britain (36), Portugal (7), Israel (25) and India (41). In contrast, this type of study is scarce in Brazil $(34,39)$.

Since that below-ground ecosystem as a whole is affected by AMF (14), they may be useful as indicators of ecosystem change. Investigations of AMF fungal dynamics can help elucidate the ecological significance of AMF associations in Central Amazonia conditions. In Central Amazonia, Guitton (21) and Oliveira (42) reported seasonal variation of AMF colonization and spore numbers in some forest and fruit species native to the region. These authors found under field conditions, an increase in AMF colonization and AMF spore numbers during the rainy season (May to December). Nevertheless, information on the influence of edaphic factors on AMF colonization and spores numbers are poorly understood in Amazonia. Oliveira (42) and Oliveira and Oliveira (43) suggest that both AMF colonization and AMF spore numbers are influenced by $\mathrm{pH}, \mathrm{Al}, \mathrm{Ca}, \mathrm{Mg}, \mathrm{K}, \mathrm{Fe}$ and $\mathrm{Mn}$ availability levels. By contrast, Guitton (21) did not find significant influence of soil factors on AMF variables. As tropical soils are exposed to high soil moisture variation during the year, another studies are necessary to evaluate the effect of soil variables on the dynamics of AMF. Thus, the objectives of this study were to describe the temporal dynamics of AMF colonization and AMF spore numbers, as well as to evaluate the effects of the pluvial precipitation, soil moisture and some chemical variables on AMF dynamics in Central Amazonia.

\section{MATERIALS AND METHODS}

\section{Study site}

This study was performed in field conditions, in an agroforestry plantation at the Federal Agrotechnical School, Manaus, Amazonas, Brazil ( $2^{\circ} 57^{\prime}$ and $3^{\circ} 10^{\prime} \mathrm{S}$ and $59^{\circ} 53^{\prime}$ and $60^{\circ} 07^{\prime} \mathrm{W}$ ), on the Aleixo Road, on a clayed Yellow Oxisol. The agroforestry plantation contains Bertholletia excelsa H.B.K, Coffea arabica L., Theobroma grandiflorum Schum. and Paullinia cupana var. sorbilis Mart.; all plantations are more than 13 old.

The climate is Ami in the Köppen classification, a rainy tropical climate. The relative humidity oscillates around $84 \%$ and an average annual precipitation of $2286 \mathrm{~mm}$ (17). In this study, the sampling months were divided in two seasons: the rainy season, between December and May; and the dry season, between June and November. The dry season is characterized by intense sun and average temperature above $35^{\circ} \mathrm{C}$ (17). Precipitation values in sampling months were: August,
September and December of $1998=47,128$ and $200 \mathrm{~mm}$, respectively; February, April, May and December of $1999=278$, 245,432 and $210 \mathrm{~mm}$, respectively; February and May of $2000=$ 355 and $299 \mathrm{~mm}$, respectively.

\section{Soil and plant root sampling}

For analyses of soil fertility, soil moisture, spore numbers and AMF root colonization at all sampling periods, soil rhizosphere $(500 \mathrm{~g})$ and roots ( $2 \mathrm{~g}$ fresh weight) from each replicate of $T$. grandiflorum and $P$. cupana were randomly collected to a depth of approximately $20 \mathrm{~cm}$. The soil rhizosphere and plant root samples were transported to the laboratory in plastic bags and stored at $4^{\circ} \mathrm{C}$ until processed.

\section{AMF root colonization}

In the laboratory, after careful rinsing with tap water, the roots were cleared in 10\% $\mathrm{KOH}$ solution for 40-60 minutes at $90^{\circ} \mathrm{C}$ in a water-bath. The roots were washed and bleached in alkaline $\mathrm{H}_{2} \mathrm{O}_{2}\left(3 \mathrm{~mL}\right.$ of $\mathrm{NH}_{4} \mathrm{OH}, 30 \mathrm{~mL}$ of $\mathrm{H}_{2} \mathrm{O}_{2}$ at $10 \%$ and $567 \mathrm{~mL}$ of water), placed in $4 \% \mathrm{HCl}$ solution for 3 minutes, and stained with glycerol-trypan blue solution $(0.05 \%)(875 \mathrm{~mL}$ lactic acid, $63 \mathrm{~mL}$ glycerol, $63 \mathrm{~mL}$ of water) at $90^{\circ}$ for 60 minute in a waterbath (27). Levels of AMF colonization were quantified according to the method of Giovanetti and Mosse (19), using 50 root segments cut into $1 \mathrm{~cm}$ long pieces.

\section{Quantification of AMF spore numbers}

Thirty gram subsamples of soil from each replicate were utilized to determine AMF spore numbers. AMF spore numbers were extracted from soil using a combination of wet sieving and decanting and sucrose-centrifugation techniques (18), utilizing sieves of 205, 105 and $40 \mathrm{~mm}$ mesh. The retained materials (soil + spore) in the sieve of the smallest mesh were transferred to 50 $\mathrm{mL}$ centrifuge tubes; distilled water was added; the tubes were shaken and centrifuged for 5 minutes at $1750 \mathrm{rpm}$. After centrifugation, the suspension was decanted carefully; sucrose solution at $20 \%$ was added. The AMF spores were counting under a stereoscopic microscope at $\mathrm{x} 4$.

\section{Soil analyses}

Before processing, the samples were sieved $(2 \mathrm{~mm}$ mesh size) and the subsamples from each replicate were used for soil moisture (SM), pH, Al, H + Al, sum of bases (SB), effective cation exchange capacity (ECEC), $\mathrm{Ca}, \mathrm{Mg}, \mathrm{K}, \mathrm{P}, \mathrm{Zn}, \mathrm{Mn}$ and $\mathrm{Fe}$ determinations. Soil moisture was determined gravimetrically by drying samples at $105^{\circ} \mathrm{C}$ for $48 \mathrm{~h}(15)$. Values of soil $\mathrm{pH}\left(\mathrm{H}_{2} \mathrm{O}\right.$, 1:2.5), $\mathrm{Ca}, \mathrm{Mg}$ and $\mathrm{Al}(\mathrm{KCl} 1 \mathrm{~N}), \mathrm{P}$ (extraction by Mehlich 1 and reading by colorimetry), $\mathrm{K}, \mathrm{Mn}, \mathrm{Zn}$ and $\mathrm{Fe}$ (Mehlich 1, atomic absorption) were determined (15). Indirectly, values of sum of bases $(\mathrm{SB}=\mathrm{Ca}+\mathrm{Mg}+\mathrm{K})$ and effective cation exchange capacity $(\mathrm{ECEC}=\mathrm{SB}+\mathrm{Al})$ also were calculated. Chemical characteristics of soil rhizosphere may be found in Table 1 . 
Table 1. Chemical characteristics of a Yellow Oxisol planted with $T$. grandiflorum and P. cupana in an agroforestry plantation in Manaus, Amazonas. The values are means (with ranges in parentheses) obtained from monthly values through the sampling periods.

\begin{tabular}{ccc}
\hline Rhizosphere variables & T. grandiflorum & P. cupana \\
\hline $\mathrm{pH}\left(\mathrm{H}_{2} \mathrm{O}, 1: 2.5\right)$ & $3.5(3.4-3.7)$ & $3.7(3.5-3.9)$ \\
$\mathrm{Al}\left(\mathrm{cmol}_{\mathrm{c} \mathrm{k}}{ }^{-1}\right)$ & $2(1.5-2.5)$ & $2.1(1.6-2.5)$ \\
$\mathrm{H}+\mathrm{Al}\left(\mathrm{cmol}_{\mathrm{c} \mathrm{kg}} \mathrm{kg}^{-1}\right)$ & $2.8(2.2-3.5)$ & $2.8(2.2-3.5)$ \\
$\mathrm{ECEC}\left(\mathrm{cmol}_{\mathrm{c} \mathrm{kg}}\right)$ & $3.5(3.1-4.6)$ & $3.6(2.9-4.7)$ \\
$\mathrm{Ca}\left(\mathrm{cmol}_{\mathrm{c} \mathrm{kg}}^{-1}\right)$ & $1(0.6-1.6)$ & $1.1(0.7-2)$ \\
$\mathrm{Mg}\left(\mathrm{cmol}_{\mathrm{c} \mathrm{kg}} \mathrm{kg}^{-1}\right)$ & $0.4(0.2-0.5)$ & $0.5(0.3-0.8)$ \\
$\mathrm{K}\left(\mathrm{mg} \mathrm{kg}^{-1}\right)$ & $31(26-42)$ & $32(27-40)$ \\
$\mathrm{P}\left(\mathrm{mg} \mathrm{kg}^{-1}\right)$ & $18(7-28)$ & $11(5-18)$ \\
$\mathrm{Zn}\left(\mathrm{mg} \mathrm{kg}^{-1}\right)$ & $4.5(3-6.7)$ & $3.5(1.6-5.3)$ \\
$\mathrm{Mn}\left(\mathrm{mg} \mathrm{kg}^{-1}\right)$ & $1.8(0.7-3.2)$ & $2(0.9-4.4)$ \\
$\mathrm{Fe}\left(\mathrm{mg} \mathrm{kg}^{-1}\right)$ & $214(115-314)$ & $130(61-225)$ \\
\hline
\end{tabular}

ECEC $=$ Effective cation exchange capacity.

\section{Experimental design and statistical analysis}

The experimental design used was completely randomized, arranged in a $2 \times 9$ factorial. The factors were represented by two fruit species ( $T$. grandiflorum and P. cupana) and nine sampling months (August/98, September/98, December/98, February/99, April/99, May/99, December/99, February/00 and May/00), with five replicates. These data were also arranged in a 2 x 2 factorial to investigate the influence of sampling seasons (dry season: August/98 and September/98, and rainy season: December/98, February/99, April/99, May/99, December/99, February/00 and May/00) on temporal variation of $\mathrm{pH}, \mathrm{Al}, \mathrm{H}+$ $\mathrm{Al}$, ECEC, Ca, Mg, K, P, Zn, Mn and Fe values during the study period. Prior to statistical analysis, AMF colonization and AMF spore numbers data were arcsin square root-transformed and square root-transformed, respectively.

AMF colonization, AMF spore numbers and edaphic variables data were analyzed by two-way ANOVA to test for differences between host species and between sampling months or seasons. To contrast treatments means Tukey's test was used at $5 \%, 1 \%$ and $0.1 \%$ (20). Pearson product-moment correlation analysis was used to relate AMF colonization and AMF spore numbers (dependent variables) with pluvial precipitation, soil moisture content and soil rhizosphere, $\mathrm{pH}$, $\mathrm{Al}, \mathrm{H}+\mathrm{Al}, \mathrm{ECEC}, \mathrm{Ca}, \mathrm{Mg}, \mathrm{K}, \mathrm{P}, \mathrm{Zn}, \mathrm{Mn}$ and Fe (independent variables) for each species and sampling months. Total regression analyses were used to test the influence of edaphicclimatic factors on dynamics of AMF natives or spore numbers independent from sampling periods and host species. Statistical software (StatSoft, Tulsa, USA) was used for this statistical analysis.

\section{RESULTS}

\section{Soil chemical variables}

Two-way ANOVA of the studied data indicated that there were significant differences in mean levels of soil variables between plant species and sampling seasons (Tables 2 and 3). Soil $\mathrm{pH}$ varied significantly between species and between

Table 2. Temporal patterns of soil factors in the rhizosphere of $T$. grandiflorum and P. cupana in an agroforestry plantation in Manaus, Amazonas.

\begin{tabular}{|c|c|c|c|c|c|c|c|c|c|}
\hline \multirow{2}{*}{ Species } & \multicolumn{3}{|c|}{$\mathrm{pH}$} & \multicolumn{3}{|c|}{$\mathrm{Al}$} & \multicolumn{3}{|c|}{ ECEC } \\
\hline & Dry $^{1}$ & Rainy $^{2}$ & Means & Dry & Rainy & Means & Dry & Rainy & Means \\
\hline & & & & \multicolumn{3}{|c|}{ - $\mathrm{cmol}_{\mathrm{c}} \mathrm{kg}^{-1}$} & \multicolumn{3}{|c|}{ - } \\
\hline T. grandiflorum & 3.4 & 3.6 & $3.5 \mathrm{~b}$ & 2.4 & 1.7 & $2.1 \mathrm{a}$ & 3.7 & 3.3 & $3.5 \mathrm{a}$ \\
\hline P. cupana & 3.6 & 3.8 & $3.7 \mathrm{a}$ & 2.2 & 1.7 & $2.0 \mathrm{a}$ & 4.0 & 3.2 & $3.6 \mathrm{a}$ \\
\hline \multirow[t]{4}{*}{ Means } & $3.5 b$ & $3.7 \mathrm{a}$ & 3.6 & $2.3 \mathrm{a}$ & $1.7 \mathrm{~b}$ & 2.0 & $3.9 \mathrm{a}$ & $3.3 b$ & 3.9 \\
\hline & \multicolumn{3}{|c|}{$\mathrm{P}$} & \multicolumn{3}{|c|}{$\mathrm{Fe}$} & \multicolumn{3}{|c|}{$\mathrm{Mn}$} \\
\hline & Dry & Rainy & Means & Dry & Rainy & Means & Dry & Rainy & Means \\
\hline & \multicolumn{3}{|c|}{ - $\mathrm{mg} \mathrm{kg}^{-1}$} & \multicolumn{3}{|c|}{------ $\mathrm{mg} \mathrm{kg}^{-1}$} & \multicolumn{3}{|c|}{------- $\mathrm{mg} \mathrm{kg}^{-1}$------- } \\
\hline T. grandiflorum & 16.2 & 19.0 & $18.0 \mathrm{a}$ & 206 & 222 & $214 \mathrm{a}$ & 0.9 & 2.6 & $1.8 \mathrm{a}$ \\
\hline P. cupana & 11.4 & 10.8 & $11.0 \mathrm{~b}$ & 109 & 150 & $130 \mathrm{~b}$ & 1.2 & 2.8 & $2.0 \mathrm{a}$ \\
\hline Means & $14.0 \mathrm{a}$ & $15.0 \mathrm{a}$ & 14.5 & $158 \mathrm{a}$ & $186 \mathrm{a}$ & 172 & $1.1 \mathrm{~b}$ & $2.7 \mathrm{a}$ & 1.9 \\
\hline
\end{tabular}

${ }^{1}$ Dry season: August and September/1998; ${ }^{2}$ Rainy season: December/1998, February, April, May and December/1999, February and May/ 2000); ECEC = Effective cation exchange capacity. 
Table 3. Summary of two-way of variance of the effect of fruit species, sampling months and seasons factors on AMF and soil AMFS in Central Amazonia edaphic-climatic conditions.

\begin{tabular}{|c|c|c|c|c|c|c|c|c|c|c|c|c|}
\hline \multirow[t]{2}{*}{$\begin{array}{l}\text { Source of } \\
\text { variation }\end{array}$} & \multirow[b]{2}{*}{ D.f } & \multicolumn{3}{|c|}{$\begin{array}{c}\text { F values } \\
\text { AMF variables }\end{array}$} & \multirow[t]{2}{*}{$\begin{array}{l}\text { Source of } \\
\text { variation }\end{array}$} & \multirow[b]{2}{*}{ D.f } & \multicolumn{6}{|c|}{$\begin{array}{c}\text { F values } \\
\text { Edaphic variables }\end{array}$} \\
\hline & & AMF & AMFS & SM & & & $\mathrm{pH}$ & $\mathrm{Al}$ & ECEC & $\mathrm{P}$ & $\mathrm{Mn}$ & $\mathrm{Fe}$ \\
\hline Species (S) & 1 & $1.6^{\mathrm{NS}}$ & $1.2^{\mathrm{NS}}$ & $0.2^{\mathrm{NS}}$ & Species (S) & 1 & $12.2 * *$ & $1.9^{\mathrm{NS}}$ & $0.2^{\mathrm{NS}}$ & $6.7^{*}$ & $0.6^{\mathrm{NS}}$ & $9.9^{* *}$ \\
\hline Months (M) & 8 & $15.6^{* *}$ & $68.6^{* *}$ & $175.8^{* *}$ & Seasons $(\mathrm{Se})$ & 1 & $15.6^{* *}$ & $45.2 * *$ & $12.2 * *$ & $0.2^{\mathrm{NS}}$ & $27.2 * *$ & $1.2^{\mathrm{NS}}$ \\
\hline $\mathrm{S} \times \mathrm{M}$ & 8 & $1.3^{\mathrm{NS}}$ & $2.8^{* *}$ & $1.8^{\mathrm{NS}}$ & $\mathrm{S} \times \mathrm{Se}$ & 1 & $0.5^{\mathrm{NS}}$ & $0.2^{\mathrm{NS}}$ & $1.5^{\mathrm{NS}}$ & $0.5^{\mathrm{NS}}$ & $0.1^{\mathrm{NS}}$ & $0.2^{\mathrm{NS}}$ \\
\hline $\mathrm{VC}$ & - & 9.6 & 10.7 & 2.5 & $\mathrm{VC}$ & - & 2.7 & 9.6 & 10.7 & 39.1 & 37.6 & 34.8 \\
\hline
\end{tabular}

D.f = Degree freedom; VC = Variation coefficient; $\mathrm{AMF}(\mathrm{S})=$ Arbuscular mycorrhizal fungi (spores); $\mathrm{SM}=$ Soil moisture; ECEC = Effective cation exchange capacity; NS = Not significant; $* P<0.05 ; * * P<0.01$.

sampling seasons ( $\mathrm{p}<0.01$ for both factors). Soil $\mathrm{pH}$ in the rhizosphere of $P$. cupana $(\mathrm{pH}=3.7)$ was significantly higher than in the rhizosphere of $T$. grandiflorum $(\mathrm{pH}=3.5)$. Similarly, soil $\mathrm{pH}$ in rainy season was significantly higher $(\mathrm{pH}=3.7)$ than in dry season $(\mathrm{pH}=3.5)($ Table 2). Soil Al, Mn and ECEC varied significantly ( $\mathrm{p}<0.01$ for all variables) only between seasons. After dry season, soil $\mathrm{Al}$ and ECEC decreased significantly from 2.3 to $1.7 \mathrm{cmol}_{\mathrm{c}} \mathrm{kg}^{-1}$ and from 3.9 to $3.3 \mathrm{cmol}_{\mathrm{c}} \mathrm{kg}^{-1}$, respectively. Contrarily, soil $\mathrm{Mn}$ increased during the rainy season (Table 2). Soil P and Fe concentrations varied only between fruit species. The concentrations of those elements in the rhizosphere of $P$. cupana $\left(\mathrm{P}=11.0 \mathrm{mg} \mathrm{kg}^{-1}\right.$ and $\mathrm{Fe}=130 \mathrm{mg}$ $\mathrm{kg}^{-1}$ ) were significantly smaller than in the rhizosphere of $T$. grandiflorum $\left(\mathrm{P}=18.0 \mathrm{mg} \mathrm{kg}^{-1}\right.$ and $\left.\mathrm{Fe}=214 \mathrm{mg} \mathrm{kg}^{-1}\right)$ (Table 2). Soil $\mathrm{Ca}, \mathrm{Mg}, \mathrm{K}, \mathrm{Zn}$ and $\mathrm{H}+\mathrm{Al}$ did not varied significantly between species or sampling seasons (data not showed).

\section{Soil moisture}

Soil moisture ranged from 26.1 to $47.1 \%$, without significant differences between host species. Significant differences (P < 0.01 ) in soil moisture content were found between the sampling months (Table 3). Soil moisture varied in response to rainy season, ranging from 31.2 to $42.1 \%$ in August 1998 (dry season) and April 1999 (rainy season), respectively.

\section{Root colonization by AMF}

P. cupana and T. grandiflorum exhibited AMF colonization ranging from $12.8 \%$ to $28.4 \%$, however without significant variations between host species (Fig. 1a and Table 3). On the other hand, significant differences $(\mathrm{P}<0.01)$ were observed between the sampling months (Table 3). The mean of AMF colonization for all treatments studied was $18.8 \%$ (data not showed). In T. grandiflorum, minimum AMF colonization of $12.8 \%$ and maximum of $28.4 \%$ were noted in August 1998 and February 2000, respectively. In P. cupana, minimum AMF colonization of $14.6 \%$ and maximum of $27.4 \%$ were observed in
August 1998 and May 2000, respectively (Fig. 1a). In August 1998, AMF colonization was significantly lower $(\mathrm{p}<0.01)$ than in other sampling months (Fig. 1b). Moreover, the higher percentages of mycorrhizal colonization occurred during the rainy season, except for the sample collected in December 1998 (beginning of the rainy season) (14.8\%), that did not differ significantly from the sample collected in September 1998 (16.4\%) (Fig. 1b).

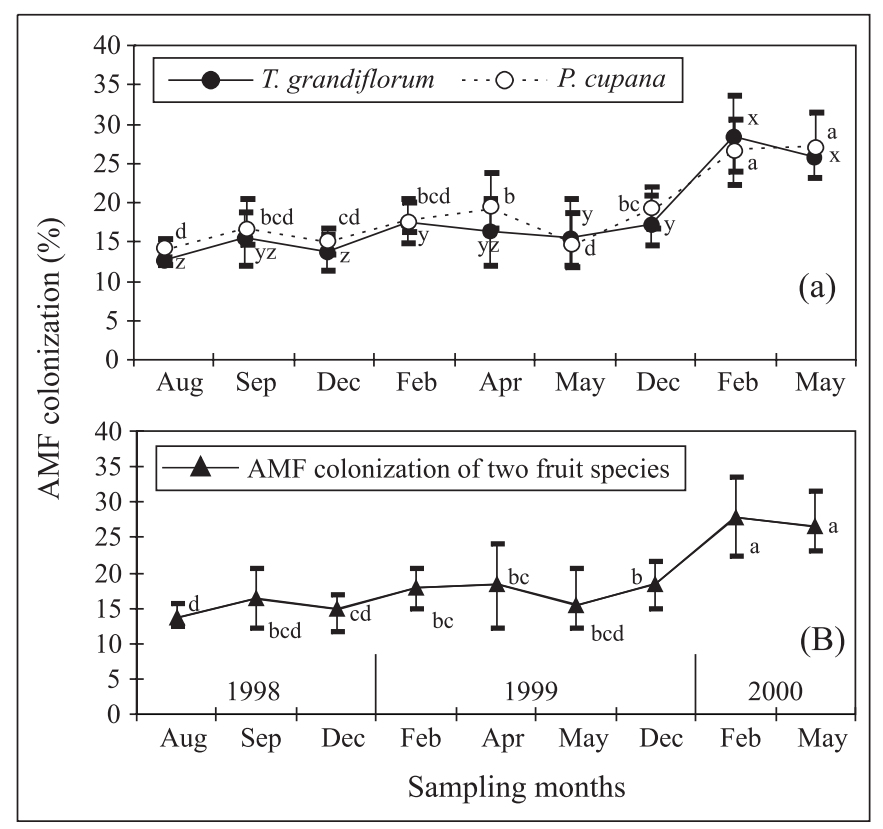

Figure 1. Temporal variation in root colonization by AMF in $T$. grandiflorum (O), P. cupana $(\bigcirc)$ plants and on the means of colonization of both fruit species $(\boldsymbol{\Delta})$ during all months analyzed. In fig. 1a: abcd: P. cupana means comparisons; xyz: T. grandiflorum means comparisons. 


\section{AMF spore number}

In the rhizospheres of both host species, AMF spore numbers (expressed as per 30 gram of dry soil) ranged from 36 to 349 , with mean number of 217 (data not showed). Mean spore numbers did not differ significantly between species (Fig. 2a and Table 3), although the variations between sampling months were significant (Table 3). The soil sample collected in August (dry season) was significantly lower $(\mathrm{p}<0.01)$ than in all the sampling performed during the rainy season (Fig. 2b).

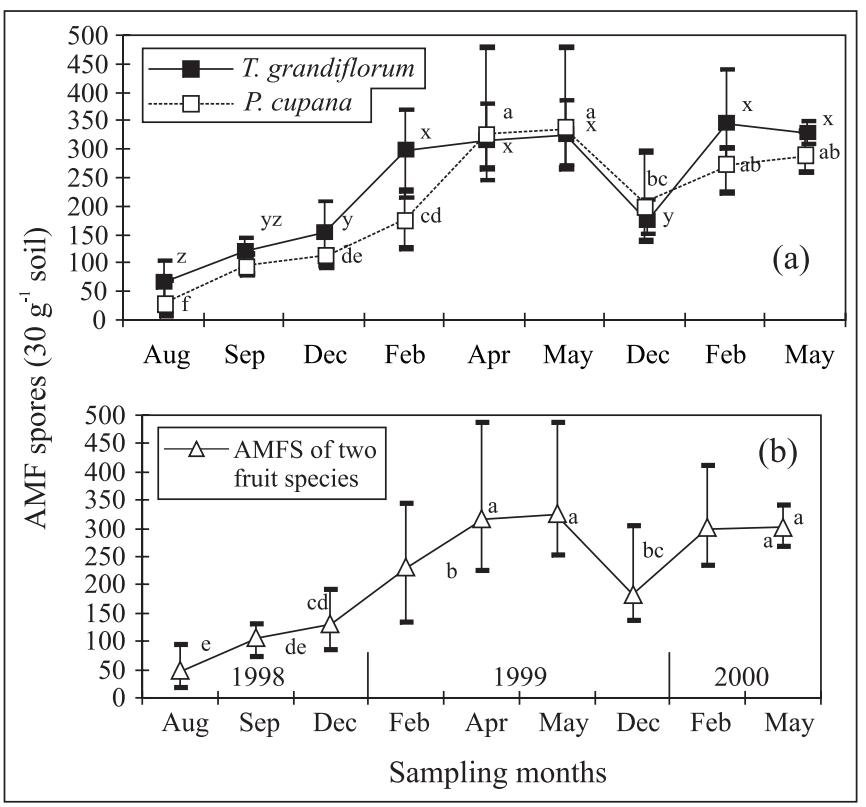

Figure 2. Temporal variation in AMF spores (AMFS) in the rhizosphere of T. grandiflorum ( $\square$ ), P. cupana $(\square)$ plants and on the means of AMF spores of both fruit species $(\triangle)$ during all months analyzed. In fig. $2 \mathrm{a}$ : abcd: $P$. cupana means comparisons; xyz: T. grandiflorum means comparisons.
The first-order interactions (host species within sampling periods) demonstrated significant differences ( $\mathrm{p}<0.01$ ) between the host species in February 1999, where higher AMF spore numbers in the rhizosphere of T. grandiflorum was found (Fig. 2a). For the sampling periods within host species, except for December 1998 (beginning of the rainy season), the data showed higher spore numbers during the rainy season for both host species.

\section{Correlation between climatic, soil and AMF variables}

Correlation analysis demonstrated that pluvial precipitation was highly significant and positively correlated to AMF spore numbers $(\mathrm{p}<0.001)$ in $T$. grandiflorum and $P$. cupana. On the other hand, only AMF colonization of T. grandiflorum -was weakly significant and positively correlated to pluvial precipitation $(\mathrm{p}<0.05)$ (Table 4). AMF colonization and AMF spore numbers were correlated $(\mathrm{p}<0.01)$ with soil moisture content (Fig. 3 and Table 4). AMF colonization was also

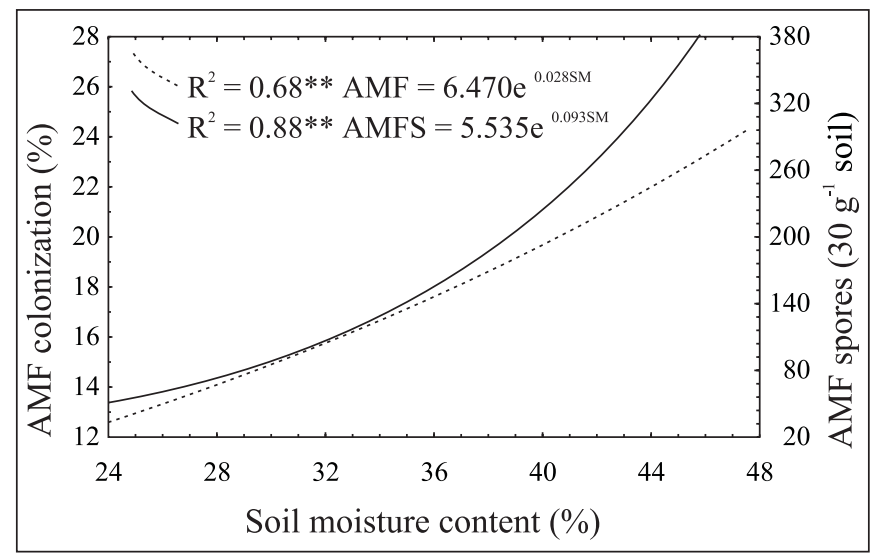

Figure 3. Total relationships $(\mathrm{n}=90)$ between AMF colonization (---), AMF spore numbers (-) and soil moisture in the rhizospheres of two studied fruit species. $* * \mathrm{p}<0.01$.

Table 4. Pearson product-moment correlation coefficients between AMF and AMFS and some edaphic variables under of T. grandiflorum and $P$. cupana during the studied period $(\mathrm{n}=9)$.

\begin{tabular}{|c|c|c|c|c|c|c|c|c|c|}
\hline Species & & $\mathrm{AMF}$ & $\mathrm{PP}$ & $\mathrm{SM}$ & $\mathrm{pH}$ & $\mathrm{Mg}$ & $\mathrm{K}$ & $\mathrm{Mn}$ & ECEC \\
\hline T. grandiflorum & AMFS & $0.7 *$ & $0.9 * * *$ & $0.9 * * *$ & $0.4^{\mathrm{NS}}$ & $0.6^{*}$ & $0.5^{*}$ & $0.7 * *$ & $-0.6^{*}$ \\
\hline \multirow[t]{2}{*}{ P. cupana } & $\mathrm{AMF}$ & 1.0 & $0.4^{\mathrm{NS}}$ & $0.7 * *$ & $0.5^{*}$ & $0.4^{\mathrm{NS}}$ & $0.4^{\mathrm{NS}}$ & $0.6^{*}$ & $0.3^{\mathrm{NS}}$ \\
\hline & AMFS & $0.5^{*}$ & $0.9 * * *$ & $0.9 * * *$ & $0.7 * *$ & $0.4^{\mathrm{NS}}$ & $0.4^{\mathrm{NS}}$ & $0.5^{*}$ & $0.1^{\mathrm{NS}}$ \\
\hline
\end{tabular}

$\mathrm{AMF}(\mathrm{S})=$ Arbuscular mycorrhizal fungi (spores); $\mathrm{PP}=$ Pluvial precipitation; $\mathrm{SM}=$ Soil moisture; $\mathrm{ECEC}=$ Effective cation exchange capacity; NS $=$ Not significant; $* P<0.05 ; * * P<0.01 ; * * * P<0.001$. 
positively correlated $(\mathrm{p}<0.05)$ with AMF spore numbers for both species as an effect of increase spore numbers during the rainy season (Fig. 4 and Table 4).

AMF colonization of $T$. grandiflorum was positively correlated with soil $\mathrm{Mg}$ and $\mathrm{K}$ concentrations. AMF spore numbers under $T$. grandiflorum was negatively correlated with ECEC. AMF colonization and AMF spore numbers in the
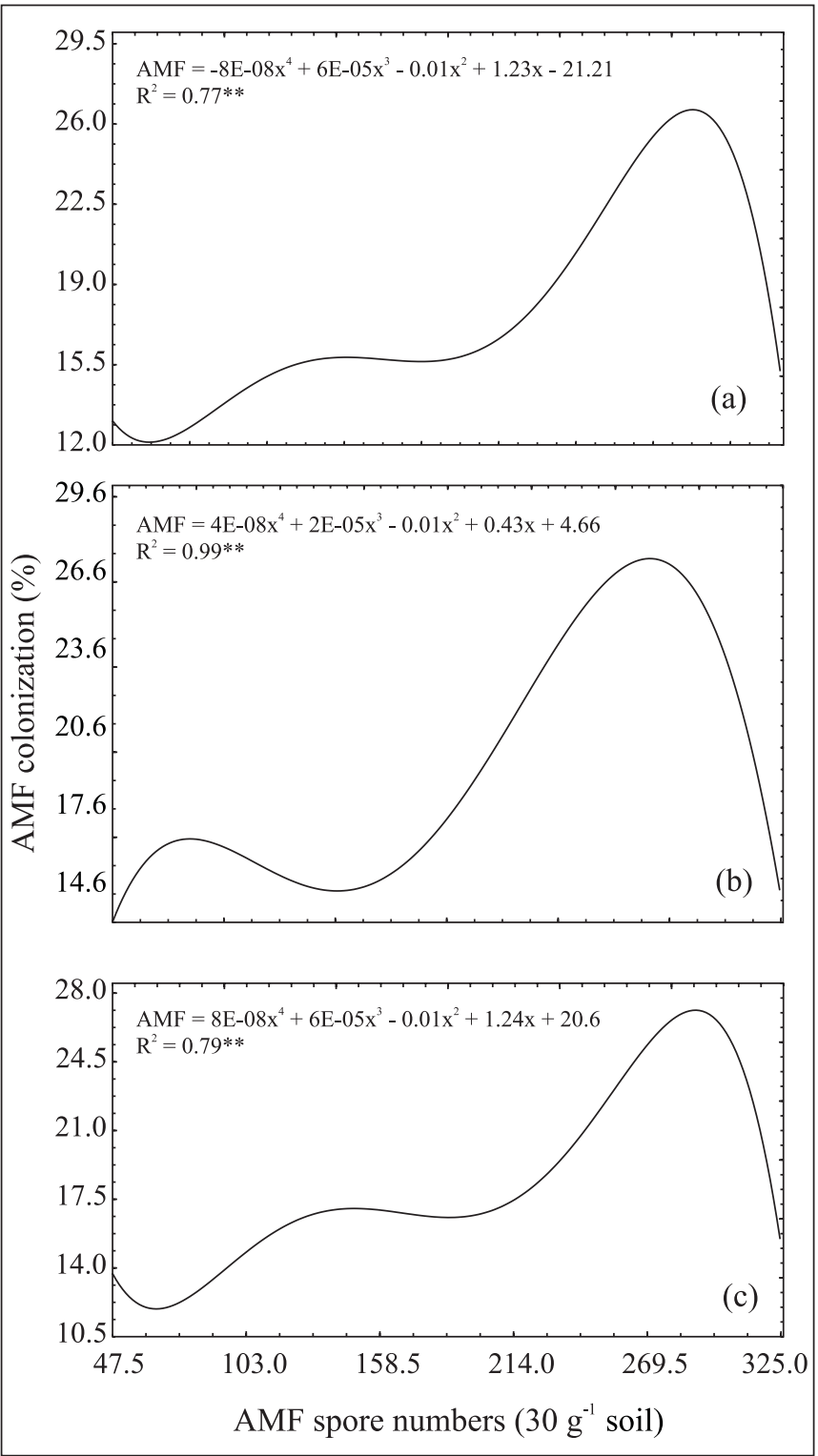

Figure 4. Relationships $(n=45)$ between AMF colonization and AMF spore numbers in the rhizospheres of $T$. grandiflorum (a) and P. cupana (b) and total relationship $(\mathrm{n}=90)$ between AMF colonization and AMF spores (c) in the rhizospheres of two studied fruit species. ** $\mathrm{p}<0.01$. rhizosphere of $P$. cupana were positively correlated with soil $\mathrm{pH}$ and $\mathrm{Mn}$ concentration (Table 4).

Comparing both host species, correlation coefficients between AMF colonization and spore numbers showed a higher coefficient in the rhizosphere of T. grandiflorum (Table 4). This result may be due to higher spore numbers in the rhizosphere of T. grandiflorum than in P. cupana, although the AMF spore numbers in T. grandiflorum did not have resulted on a significant increase on AMF colonization of this host specie (Table 3).

\section{DISCUSSION}

The AMF colonizations for $T$. grandiflorum and $P$. cupana was lower than levels observed by Oliveira et al. (46) (28.3\%) for T. grandiflorum, and those mentioned by Chu (8) $(61.7 \%)$ and Costa et al. (11) (51\%) for the P. cupana. However, they were higher than those observed by Oliveira et al. (45) that reported values of $11.2 \%$ and $10.7 \%$ of AMF colonization for $T$. grandiflorum and P. cupana, respectively, in the same agroforestry plantation studied here.

Seasonal changes in AMF colonization have been studied in several plant species $(6,41,51,60)$, although most of these studies have failed to find consistent seasonal patterns of AMF colonization. In the present study, however, for both fruit species, the seasonal fluctuations of mycorrhizal colonization and AMF spore numbers followed the same trend during the sampling months (Figs. 1 and 2). The results of this study indicate a influence of pluvial precipitation (Table 4) on levels of AMF colonization $(41,50,59)$ in Central Amazonia climatic conditions. The average level AM colonization observed during the sampling months agreed, in general terms, with the results of Guitton (21), Oliveira et al. $(45,46)$ and Oliveira (42), who reported, respectively, higher AMF colonization during the dry season in forest species and during the rainy season in fruit species of Central Amazonia.

AMF spore numbers were strongly seasonal with increasing numbers of AMF spores as the rainy season progressed. Similar seasonal patterns in spore number were observed in other studies in Brazil $(21,34,39)$, with gradual increases in the spore numbers during the rainfall period, followed of decreases during the dry period. However, this seasonal variation can be significant or not, depending on the species and evaluation periods (months), as can be verified by the significant interaction between factors and sampling months (Table 3 ).

Allen and Allen (1) explained that seasonal variation occur mainly because of rainfall fluctuation. Siqueira (54) affirmed that the cyclical changes in soil moisture is what stimulates AMF sporulation. These comments contribute to explain of the remarkably seasonal behavior of the spores in this study.

Several studies had demonstrated that soil nutrient concentration is spatially and temporally varied in all ecosystems $(22,30,32,42)$. The results of this investigation give some support 
to a strong influence of edaphic factors, such as soil moisture, $\mathrm{pH}, \mathrm{ECEC}, \mathrm{Mg}, \mathrm{K}$ and $\mathrm{Mn}(16,40,41,42,52)$ on symbiotic association in the acid soils and nutrient-limited soils of Central Amazonia. According to Hayman (24), level of soil fertility is believed to be an important factor influencing the AMF population. Studies have showed that plants forming associations with AMF had improved plant growth in acid soils that were limed (10), while in other acid soils, a positive AM fungal effect was found without the need to increase $\mathrm{pH}(23,44,57)$. In an Oxisol soil of Central Amazonia, AMF colonization and populations of AMF in the rhizosphere of $P$. cupana and Bactris gasipaes plants have been positively correlated to $\mathrm{pH}, \mathrm{Al}, \mathrm{Ca}, \mathrm{Mg}, \mathrm{K}$ and $\mathrm{Mn}$ $(42,43)$ and negatively correlated to ECEC $(42)$.

Seely (53), Jacobson (26) and Mohammad et al. (40) reported that biotic factors are relatively less important than abiotic factors for establishing population patterns and found that the duration of moisture availability determines the level of AMF colonization. Thus, the improvement of soil fertility, especially the increase of $\mathrm{pH}$, availability of $\mathrm{Mg}, \mathrm{K}$ and $\mathrm{Mn}$, and soil moisture provided favorable environment for mycorrhizal formation and function in terra firme soils of Central Amazonia.

The positive correlation between soil moisture and AM colonization reported here disagree with several studies $(4,29,56)$, according to whom development of AMF is favored by reduced soil water and better soil aeration. Other studies $(7,13,37)$ suggested non-direct relationship between AMF colonization and soil moisture. In contrast, our results agree with Paula and Siqueira (47), Braunberger et al. (5); Miller et al. (38) and He et al. (25) that found positive correlation between these variables. In Brazil, Paula and Siqueira (47) observed in greenhouse, maximum increase AMF colonization levels in soil moisture levels ranging between $30 \%$ and $60 \%$. In the present experiment, the maximum moisture registered in the rhizospheres of fruit plants was below $50 \%$. Hence, it is possible that the moisture observed in this study did not cause significant reduction in soil aeration to the point of compromising the mycorrhizal association in these environmental conditions. It showed also, that soil moisture change during different phases of the sporulation and germination processes as observed by Daniels and Trappe (12), Koske (28) and Tommerup (58, apud 47).

The relationship AMF colonization and soil moisture may be associated, also, with the development of the plants root system due to the increase in the water content of soil $(42,45)$; with the formation of new roots, there will be a simultaneous increase in nutrients absorption and liberation of root exsudates, stimulating mycorrhizal spore germination and subsequent infection $(25,42,45)$. Oliveira et al. (45) and Oliveira (42) suggested also that the tender cortical tissue of new roots may be more susceptible to infection and colonization by AMF.

Reid and Bowen (49, apud 47) reported that the diameter of primary roots and the rates of root colonization decreased with the reduction in the water content of the soil. Recent evidence $(42,45,46)$ indicated that elevation in soil moisture can increase the colonization of some plants in Amazonian edaphic-climatic conditions.

According to Maschio et al. (35), AM fungi have adaptability for colonizing areas that present adverse physical, chemical and biological conditions, and they depend on moisture for multiplication. Studies affirm that mycorrhizal sporulation is linked to better soil moisture conditions $(5,42)$, which is observed in Fig. 3 and Table 4 as increases in the numbers of spores in the rhizospheres of plants as a function of increased soil moisture.

Some reports in the literature $(9,36,47)$ indicate that the colonization process and mycorrhizal sporulation are not always correlated. For other authors $(25,48)$, when soil conditions are suitable for spore germination, mycorrhizal colonization increases and spore numbers decreases. The linear positive (Table 4) and quadric terms (Fig. 4) registered here between AMF colonization and spore numbers in the rhizosphere of host fruit species, are contrary to these observations, could be due to the fact that an increase in spore numbers in soils with reduced potential of inoculum by AMF can enhance root colonization before an expected decrease (negative relationship). This positive relationships registered here suggest that increasing the soil spore numbers, also increase the possibility of them to germinate and to reach host plant roots, beginning therefore, the symbioses infection process and roots colonization of the host species.

In this experiment, pluvial precipitation and yearly fluctuations in soil condition, such as soil moisture and some soil chemical variables had significant effects on the temporal spore numbers and colonization of AMF fungi in the rhizospheres of $T$. grandiflorum and $P$. cupana. Further research is needed to determine whether the seasonal patterns observed in this study was caused by different fungal types and phenological variations among fungal types or by the seasonal response of a single fungus type. Finally, it is clear that learning more about the ecology and intricacies of the association is crutial for attaining a good understanding of AMF formation and function in Central Amazonia edaphic-climatic conditions.

\section{RESUMO}

\section{Dinâmica sazonal de fungos micorrízicos arbusculares em plantas de Theobroma grandiflorum Schum e Paullinia cupana Mart. de um sistema agroflorestal na Amazônia Central, Amazonas, Brasil}

A dinâmica sazonal de fungos micorrízicos arbusculares (FMA) foi investigada na rizosfera de duas espécies frutíferas em um ecossistema de terra firme na Amazônia Central. Adotouse o delineamento inteiramente casualizado, em arranjo fatorial 2 x 9 , onde os fatores representaram duas espécies frutíferas 
(Theobroma grandiflorum e Paullinia cupana) e nove meses de coleta (agosto, setembro e dezembro/1998, fevereiro, abril, maio e dezembro/1999, fevereiro e maio/2000), com cinco repetições. O percentual de colonização micorrízica para as duas espécies atingiu valores máximos nos meses de fevereiro e maio de 2000 (estação chuvosa). Similarmente, nos meses de abril e maio de 1999, fevereiro e maio de 2000 (estação chuvosa) foram registrados os maiores números de esporos de FMA para ambas espécies. A precipitação pluvial foi significativamente e positivamente correlacionada com o número de esporos para as duas espécies, e significativamente correlacionada apenas com a colonização micorrízica de $P$. cupana. $\mathrm{O}$ teor de umidade do solo foi positivamente correlacionado com o número de esporos e colonização por FMA para ambas espécies. A colonização micorrízica e o número de esporos de FMA foram positivamente correlacionados com os teores de $\mathrm{Mg}$ e $\mathrm{K}$ no solo. O número de esporos foi ainda negativamente correlacionado com a CTC efetiva do solo. A colonização micorrízica e o número de esporos de FMA na rizosfera de $P$. cupana foram positivamente correlacionadas com o pH e a concentração de Mn no solo. A colonização micorrízica foi também positivamente correlacionada com o número de esporos de FMA para as duas espécies avaliadas. Em conclusão, esse estudo mostrou que tanto a colonização micorrízica como a esporulação são sazonais e dependentes da espécie de planta hospedeira, precipitação pluvial, teor de umidade e da química do solo, nas condições da Amazônia Central.

Palavras-chave: fungos micorrízicos arbusculares, Theobroma grandiflorum, Paullinia cupana, sistema agroflorestal, Amazônia Central

\section{REFERENCES}

1. Allen, E.B.; Allen, M.F. Natural re-establishment of vesiculararbuscular mycorrhiza following strip mine reclamation in Wyoming. J. Appl. Ecol., 17, 139-147, 1980.

2. Anand, M.; Ma, K.M.; Okonski, A.; Levin, S.; McCreath, D. Characterising biocomplexity and soil microbial dynamics along a smelter-damaged landscape gradient. The Sci. Total Environ., 311, 247-259, 2003.

3. Beare, M.H.; Hu, S.; Coleman, D.C., Hendrix, P.F. Influence of mycelial fungi on soil aggregation and organic matter storage in conventional and no-tillage soils. Appl. Soil, 5, 211-219, 1997.

4. Bolgiano, N.C.; Safir, G.R.; Warncke, D.D. Mycorrhizal infection and growth of onion in the field in relation to phosphorus and water availability. J. Am. Soc. Hort. Sci., 108, 819-825, 1983.

5. Braunberger, P.G.; Abbott, L.K.; Robson, A.D. The effect of rain in the dry-season on the formation of vesicular-arbuscular mycorrhizas in the growing season of annual clover-based pastures. New Phytol., 114, 457-468, 1994.

6. Brundrett, M. Mycorrhizas in natural ecosystems. Adv. Ecol. Res., 21, 171-313.

7. Carvalho, L.M.; Caçador, I.; Martins-Loução, M.A. Temporal and spatial variation of arbuscular mycorrhizas in salt marsh plants of the Tagus estuary (Portugal). Mycorrhiza, 11, 303-309, 2001.
8. Chu, E.Y. Quantificação de gêneros de micorriza vesicular-arbusculares nas culturas de pimenta-do-reino, guaraná e dendê, na Amazônia Oriental. I Simpósio do Trópico Úmido, EMBRAPA-CPATU, Belém, 1986, p. 58.

9. Clapp, J.P.; Young, J.P.W.; Merryweather, J.; Fitter, A. Diversity of fungal symbionts in arbuscular mychorrizas from a natural community. New Phytol., 130, 259-265, 1995.

10. Clark, C.A.; Zeto, S.K.; Zobel, R.W. Arbuscular mycorrhizal fungal isolate effectiveness on growth and root colonization of Panicum virgatum in acidic soil. Soil Biol. Biochem., 31, 1757-1763, 1999.

11. Costa, N.L.; Costa, R.S.C.; Paulino, V.T. Resposta do guaranazeiro à inoculação de micorrizas vesículo-arbusculares. EMBRAPA-CPAF. Comunicado Técnico, 1991, p. 1-6.

12. Daniels, B.A.; Trappe, J.W. Factors affecting spore germination of the VAM Fungus, Glomus epigaeus. Mycologia, 72, 456-471, 1980 .

13. Dhillion, S.S.; Ampornpan, L. The influence of inorganic nutrient fertilization on the growth, nutrient composition and vesiculararbuscular mycorrizal colonization of pretransplant rice (Oryza sativa L.) plants. Biol. Fertil. Soils, 13, 85-91, 1992.

14. Douds Jr.; D.D.; Millner, P. Biodiversity of arbuscular mycorrhizal fungi in agroecosystems. Agricul. Ecosyst. Environ. 74, 77-93, 1999.

15. Embrapa. Manual de métodos de análise de solos. Serviço Nacional de Levantamento e Conservação do Solo. Embrapa, Rio de Janeiro, 1997, 212p.

16. Entry, J.A.; Rygiewicz, P.T.;Watrud, L.S.; Donnelly, P.K. Influence of adverse soil conditions on the formation and function of Arbuscular mycorrhizas. Adv. Environ. Res., 7, 123-138, 2002.

17. Figueroa, S.N.; Nobre, C.A. Precipitions distribution over Central and Western Tropical South America. Climálise-Boletim de Monitoramento e Análise Climática, 5, 36-45, 1990.

18. Gerdemann, J.W.; Nicolson, T.H. Spores of mycorrhizal Endogone species extracted from soil by wet sieving and decating. Trans. Br Mycol. Soc., 46, 235-244, 1963.

19. Giovanetti, M.; Mosse, B. An evaluation of techniques for measuring vesicular arbuscular mycorrhizal infection in rots. New Phytol., 84, 489-500, 1980

20. Gomez, K.A.; Gomez, A.A. Statistical procedures for agricultural research. John Wiley \& Sons, New York, 1984, 680p.

21. Guitton, T.L. Micorrizas vesículo-arbusculares em oito espécies florestais da Amazônia: Efeitos de fatores sazonais e edáficos em plantios experimentais de terra firme na região de Manaus - AM. Manaus, 1996, 81p. (Dissertação de Mestrado. Instituto Nacional de Pesquisas da Amazônia/Universidade Federal do Amazonas. INPA/ UFAM).

22. Gupta, P.L.; Rorison, I.H. Seasonal differences in the availability of nutrients down a podzolic profile. J. Ecol., 11, 1197-1204, 1974.

23. Guzman-Plazola, R.A.; Ferrera-Cerrato, R.; Etchevers, J.D. Leucaena leucocephala, a plant of hight mycorrhizal dependence in acid soils. Leucaena Res. Rep., 9, 69-73, 1988.

24. Hayman, D.S. Influence of soils and fertility on activity and survival of vesicular-arbuscular mycorrhizal fungi. Phytopathology, 72, 11191125,1982

25. He, X.; Mouratov, S.; Steinberger, Y. Temporal and spatial dynamics of vesicular-arbuscular mycorrhizal fungo under the canopy of Zygophyllum dumosum Boiss. in the Negev Desert. J. Arid Environ., 52, 379-387, 2002

26. Jacobson, K. Moisture and substrate stability determine VAmycorrhizal fungal community distribution and structure in arid grassland. J. Arid Environ., 35, 59-75.

27. Kormanick, P.P.; Bryan, W.C.; Schultz, R.C. Procedures and equipament for staining large numbers of plant root samples for endomycorrhizal assay. Can. J. Microbiol., 26, 536-538, 1980.

28. Koske, R.E. Gigaspora gigante: observations on spore germination of a VA-mycorrhizal fungus. Mycologia, 73, 288-300, 1981. 
29. Le Tacon, F.; Skinner, F.A.; Mosse, B. Spore germination and hyphal growth of a vesicular-arbuscular mycorrhizal fungus, Glomus mossae (Gerdemann and Trappe), under decreased oxygen and increased carbon dioxide concentrations. Can. J. Microbiol., 29, 1280-1285, 1983.

30. Lodge, D.J.; McDowell.; W.H.; Swiney, C.P. The importance of nutrient pulses in tropical forests. Trends Ecol. Evol., 9, 384-387, 1997.

31. Lorgio, E.A.; Julio, R.G.; Peper, L.M. Variation in soil microorganisms and nutrients underneath and outside the canopy of Adesimia bedwellii (Papilionaceae) shrubs in arid coastal Chile following drought and above average rainfall. J. Arid Environ., 42, 61-70, 1999.

32. Marschner, H. The Mineral Nutrition of Higher Plants. Academic Press, London, 1995, 674p.

33. Marschner, H.; Dell, B. Nutrient uptake in mycorrhizal symbiosis. Plant Soil, 159, 89-102, 1994.

34. Martins, C.R.; Miranda, J.C.C.; Miranda, L.N. Contribuição de fungos micorrízicos arbusculares nativos no estabelecimento de Aristida setifolia Kunth em áreas degradadas do Cerrado. Pesq. Agropec. Bras., 34, 665-674, 1999.

35. Maschio, L.; Gaiad, S.; Montoya, L.; Curcio, G.R.; Rachwall, M.F.G.; Camargo, C.M.S.; Batti, A.M.P. Microrganismos e auto-sustentação de ecossistemas em solos alterados. I Simpósio Nacional sobre Recuperação de Áreas Degradadas, UFPR/Fundação de Pesquisas Florestais do Paraná, Curitiba, 1992, p. 440-445.

36. Merryweather, J.; Fitter, A. The arbuscular mycorrhizal fungi of Hyacinthoides non-scripta. II. Seasonal and spatial patterns of fungal populations. New Phytol., 138, 131-142, 1998.

37. Miller, J.C.; Rajapakse, S.; Garber, R.K. Vesicular-arbuscular mycorrhizae in vegetable crops. Hortscience, 21, 974-984, 1986.

38. Miller, R.M.; Smith, C.I.; Jastrow, J.D.; Bever, J.D. Mycorrhizal status of the genus Carex (Cyperaceae). Am. J. Bot., 86, 547-553, 1999.

39. Miranda, J.C.C.; Miranda, L.N. Micorriza arbuscular. In: Vargas, M.A.T., Hungria, M. (eds.). Biologia dos solos dos Cerrados. EMBRAPA-CPAC, Planaltina, 1997, p. 69-123.

40. Mohammad, M.J.; Hamad, S.R.; Malkawit, H.I. Population of arbuscular mycorrhizal fungi in semi-arid environment of Jordan as influenced by biotic and abiotic factors. J. Arid Environ., 53, 409417, 2003.

41. Muthukumar, T.; Udaiyan, K. Seasonality of vesicular-arbuscular mycorrhizae in sedges in a semi-arid tropical grassland. Acta Oecologica, 23, 337-347, 2002.

42. Oliveira, A.N. Fungos micorrízicos arbusculares e teores de nutrientes em plantas de cupuaçu e guaraná de um Sistema Agroflorestal na região de Manaus, AM. Manaus, 2001, 150p. (Dissertação de Mestrado. Universidade Federal do Amazonas. UFAM).

43. Oliveira, A.; Oliveira, L.A. Características químicas do solo, esporulação e colonização micorrízica em plantas de cupuaçuzeiro e de pupunheira na Amazônia Central. Rev. ciênc. agrár., 40, 33-44, 2003.

44. Oliveira, A.N.; Oliveira, L.A. Associação micorrízica e teores de nutrientes nas folhas de cupuaçuzeiro (Theobroma grandiflorum) e guaranazeiro (Paullinia cupana) de um sistema agroflorestral em Manaus, Amazonas. R. Bras. Ci. Solo, 28, 1063-1068, 2004.
45. Oliveira, A.N.; Oliveira, L.A.; Moreira, F.W. Micorrizas arbusculares em cupuaçu e guaraná de um sistema agroflorestal de terra firme no Município de Manaus, AM. VII FertBio, Sociedade Brasileira de Microbiologia, Caxambú, 1998, p. 617.

46. Oliveira, A.N.; Oliveira, L.A.; Ramos, M.B.P. Fungos endomicorrízicos em cupuaçuzeiro (Theobroma grandiflorum Schum) e pupunheira (Bactris gasipaes H.B.K) em um solo de terra firme da Amazônia. I Mostra Técnico-Científica da Universidade Federal do Amazonas, Manaus, 1999, p. 12.

47. Paula, M.A.; Siqueira, J.O. Efeitos da umidade do solo sobre a simbiose endomicorrízica em soja: I. Colonização radicular, esporulação, nodulação e acúmulo de nitrogênio. R. Bras. Ci. Solo, 11, 283-287, 1987.

48. Ragupathy, S.; Mahadevan, A. Distribution of vesicular-arbuscular mycorrhizae in the plants and rhizosphere soils of the tropical plains, Tamil Nadu, India. Mycorrhiza, 3, 123-136, 1993.

49. Reid, C.P.; Bowen, G.D. Effects of soil moisture on VA mycorrhiza formation and root development in Medicago. In: Harley, J.L., Scott, $\mathrm{R}$ (eds.). The soil-root interface, Academic Press, London, p. 211219, 1979.

50. Saito, M.; Kato, T. Effects of low temperature and shade on relationships between nodulation, vesicular-arbuscular mycorrhizal infection and shoot growth of soybeans. Biol. Fertil. Soils, 17, 206211, 1994.

51. Sanders, I.R.; Fitter, A.H. The ecology and functioning of vesiculararbuscular mycorrhizas in co-existing grass land species. I. Seasonal patterns of mycorrhizal occurrence and morphology. New Phytol., 120, 517-524, 1992.

52. Sano, S.M.; Abbott, L.K.; Solaiman, M.Z.; Robson, A.D. Influence of liming, inoculum level and inoculum placement on root colonization of subterranean clover. Mycorrhiza, 12, 285-290, 2002.

53. Seely, M.K. Sand dune communities. In: Polis, G.A. (eds.). The Ecology of Desert Communities. AZ: University of Arizona Press, Tucson, 1991, p. 348-382.

54. Siqueira, J.O. Biologia do Solo. ESAL/FAEPE, Lavras, Minas Gerais, 1993, 230p

55. Smith, S.E.; Read, D.J. Mycorrhizal Symbiosis. Academic Press, San Diego, 1997, 605p.

56. Sylvia, D.M.; Schenck, N.C. Germination of chlamydospores of three Glomus species as affected by soil matric potential and fungal contamination. Mycologia, 75, 30-35, 1983.

57. Sylvia, D.M.; Wilson, D.O.; Graham, J.H.; Maddox, J.J.; Millner, P.; Morton, J.B.; Skipper, H.D.; Wright, S.F.; Jarstfer, A.G. Evaluation of vesicular arbuscular mycorrhizal fungi in diverse plants and soils. Soil Biol. Biochem., 25, 705-713, 1993.

58. Tommerup, I.C. Effect of soil water potential on spore germination by vesicular-arbuscular mycorrhizal fungi. Trans. Br. Mycol. Soc., 83, 193-202, 1984.

59. Udaiyan, K.; Karthikeyan, A.; Muthukumar, T. Influence of edaphic and climatic factors on dynamics of root colonization and spore density of vesicular-arbuscular fungi in Acacia farnesiana Willd. and A. planifrons W. et A. Tree, 11, 65-71, 1996.

60. Wright, S.F.; Upadhyaya, A. A survey of soils for aggregate stability and glomalin, a glycoprotein produced by hyphae of arbuscular mycorrhizal fungi. Plant Soil., 198, 97-107, 1998. 